\title{
Corrigendum
}

\section{Design and assessment of future livestock farming systems: integrating Global and Local stakes - CORRIGENDUM}

\section{Lecomte Philippe, Tourrand Jean-Francois and Poccard Chapuis René}

doi:10.1017/S2040470010001135; published by Cambridge University Press, 8 November 2010

In the abstract by Lecomte Philippe, Tourrand Jean-Francois and Poccard Chapuis René (2010) presented in Advances in Animal Biosciences, the author names were listed incorrectly with the authors' given names and family names in the wrong sequence. The correct authorship is:

Philippe Lecomte, Jean-Francois Tourrand and René Poccard Chapuis

The editors apologise to the authors and readers for this mistake.

\section{Reference}

Philippe L, Jean-Francois T and René PC 2010. Design and assessment of future livestock farming systems: integrating Global and Local stakes. Advances in Animal Biosciences 1, 495-496. 